\title{
EFFECT OF SOCIO-DEMOGRAPHIC FACTOR AND DEMOCRATIC LEADERSHIP ON VILLAGE MIDWIFE PERFORMANCE IN IUD CONTRACEPTIVE SERVICE IN JOMBANG DISTRICT, EAST JAVA
}

\author{
Ratna Dewi Permatasari'1), Uki Retno Budihastuti2), \\ Didik Gunawan Tamtomo3) \\ ${ }^{1)}$ Masters Program in Public Heath, Sebelas Maret University \\ 2)Department of Obstetric and Gynecology, Dr. Moewardi Hospital, Surakarta \\ 3) Faculty of Medicine, Sebelas Maret University
}

\begin{abstract}
Background: The threat of population explosion in Indonesia is real. Longterm contraception program is an alternative strategy for controlling population growth rate. The slowering achievement of IUD contraceptive target for the last two years has become a central concern at the District Health Office Jombang, East Java. Sub-optimal quality of IUD contraceptive service, high drop-out rate, high unmet-need, and unsystematic family planning reporting and recording, are assumed to be the causes of the underachievement. This study aimed to examine the effect of socio-demographic factor and democratic leadership on village midwife performance in IUD contraceptive service in Jombang District, East Java.
\end{abstract}

Subjects and Method: This was an analytic observational study with crosssectional design. It was conducted in 12 community health centers in Jombang District, East Java, from March to May 2017. A sample of 120 women of reproductive age was selected for this study by simple random sampling. The dependent variable was village midwife performance. The independent variables were knowledge, self-efficacy, compensation, democratic leadership, and work motivation. The data were collected by a pre-tested questionnaire, and were analyzed by path analysis model.

Results: Midwife performance was positively affected by higher education $(b=5.19 ; \mathrm{SE}=0.53 ; \mathrm{p}<0.001)$, stronger work motivation $(\mathrm{b}=0.48 ; \mathrm{SE}=0.07$; $\mathrm{p}<0.001)$, better knowledge $(\mathrm{b}=0.21 ; \mathrm{SE}=0.08 ; \mathrm{p}=0.006)$, stronger selfefficacy $(b=0.18 ; \mathrm{SE}=0.08 ; \mathrm{p}=0.023)$, and democratic leadership $(b=0.14$; $\mathrm{SE}=0.05 ; \mathrm{p}=0.008)$. Self-efficacy was affected by education $(\mathrm{b}=1.16 ; \mathrm{SE}=$ $0.62 ; \mathrm{p}=0.063)$, knowledge $(\mathrm{b}=0.35 ; \mathrm{SE}=0.08 ; \mathrm{p}<0.001)$, democratic leadership $(b=0.23 ; \mathrm{SE}=0.04 ; \mathrm{p}<0.001)$. Work motivation was affected by compensation $(b=0.65 ; \mathrm{SE}=0.16 ; \mathrm{p}<0.001)$, democratic leadership $(b=0.31$; $\mathrm{SE}=0.07 ; \mathrm{p}<0.001)$, knowledge $(\mathrm{b}=0.29 ; \mathrm{SE}=0.09 ; \mathrm{p}<0.001)$, and selfefficacy $(b=0.17 ; \mathrm{SE}=0.09 ; \mathrm{p}=0.058)$.

Conclusion: Midwife performance was positively affected by education, work motivation, education, self efficacy, and democratic leadership.

Keywords: midwife performance, socio-demographic factor, democratic leadership, IUD contra-ceptive, family planning

Correspondence: Ratna Dewi Permatasari. Masters Program in Public Health, Sebelas Maret University, Jl. Ir. Sutami 36 A, Surakarta 57126, Central Java, Indonesia. Email: wahib.rifai81@gmail.com.

Mobile: +6281334059159. 